\title{
KAJIAN KARAKTERISTIK KIMIA DAN SENSORIS FRUIT LEATHER BEBERAPA VARIETAS PISANG (Musa spp.) DENGAN VARIASI PENAMBAHAN RUMPUT LAUT (Kappaphycus alvarezii)
}

\author{
STUDY OF CHEMICAL AND SENSORY CHARACTERISTICS SEVERAL VARIETIES OF \\ BANANA FRUIT LEATHER (Musa spp.) WITH ADDITION OF SEAWEED (Kappaphycus \\ alvarezii) VARIATION
}

\author{
Ana Mufidatun Ni'mah ${ }^{1)}$, Bambang Sigit Amanto ${ }^{1)}$, Esti Widowati ${ }^{1)}$ \\ 1) Program Studi Ilmu dan Teknologi Pangan Universitas Sebelas Maret
}

email: ana.mufidatun@gmail.com

\begin{abstract}
In this research, several varieties of banana fruit leather (Kapas, Kepok Kuning, and Nangka) were made with the addition of seaweed variation $(0 \% ; 7,5 \%$; and $15 \%)$ in order to determine the chemical characteristics (moisture content, ash content, reducing sugar content, and dietary fiber content) and sensory characteristics and to get the best fruit leather of each banana varieties used. The design of this study used Completely Randomized Design (CRD) with one factor, i.e. the concentration of seaweed. Each of these treatment was conducted through two replications of sample and three times repeated analysis. The data obtained were analyzed with one way ANOVA and followed by DMRT if there was any significant different at significance level $\alpha=5 \%$. Based on the research result can be seen that the higher concentration of seaweed addition caused an increase in ash content, reducing sugar content, and dietay fiber content of banana Kapas fruit leather, banana Kepok Kuning fruit leather, and banana Nangka fruit leather, but decrease in the levels of moisture content in all varieties of banana fruit leather. In terms of sensory, all varieties of banana fruit leather were accepted by the panelists and in the average, the addition of seaweed had no significant effect on sensory characteristics. The best fruit leather of each banana varieties were fruit leather with $15 \%$ seaweed addition.
\end{abstract}

Keywords: banana varieties, fruit leather, seaweed.

\begin{abstract}
ABSTRAK
Dalam penelitian ini dibuat fruit leather beberapa varietas pisang (pisang kapas, pisang kepok kuning, dan pisang nangka) dengan variasi penambahan rumput laut $(0 \%$; 7,5\%; dan 15\%) dengan tujuan untuk mengetahui karakteristik kimia (kadar air, kadar abu, kadar gula reduksi, dan kadar serat pangan) dan karakteristik sensoris, serta untuk mendapatkan fruit leather terbaik pada masing-masing varietas pisang yang digunakan. Rancangan penelitian ini menggunakan Rancangan Acak Lengkap (RAL) dengan satu faktor yaitu konsentrasi rumput laut. Masing-masing perlakuan dilakukan dua kali ulangan sampel dan tiga kali ulangan analisis. Data yang diperoleh dianalisis dengan metode one way ANOVA dilanjutkan dengan DMRT apabila terdapat perbedaan pada taraf signifikansi $\alpha=5 \%$. Berdasarkan hasil pengamatan diketahui bahwa dengan semakin tinggi konsentrasi rumput laut yang ditambahkan mengakibatkan terjadinya peningkatan kadar abu, kadar gula reduksi, dan kadar serat pangan pada fruit leather pisang kapas, fruit leather pisang kepok kuning, dan fruit leather pisang nangka, namun terjadi penurunan pada kadar air fruit leather semua varietas pisang. Fruit leather semua varietas pisang dari segi sensoris diterima oleh panelis dan rata-rata penambahan rumput laut tidak berpengaruh signifikan terhadap karakteristik sensoris. Fruit leather yang terbaik pada masing-masing varietas pisang yaitu fruit leather dengan penambahan $15 \%$ rumput laut.
\end{abstract}

Kata kunci : fruit leather, rumput laut, varietas pisang

\section{PENDAHULUAN}

Pisang (Musa spp.) merupakan tanaman sepanjang musim dengan banyak keunggulan. Seluruh bagian tanaman pisang dapat dimanfaatkan untuk berbagai keperluan, terutama adalah buahnya. Dalam daging buah pisang yang sudah masak terkandung banyak kalori dan karbohidrat dalam bentuk gula. Selain itu, terkandung pula protein, serat, dan mineral yang cukup tinggi (Cahyono, 1995). Pisang di Indonesia beraneka ragam jenisnya antara lain pisang kepok, raja, kapas, mas, nangka, dan ambon, yang tersebar di berbagai daerah di Indonesia. Menurut Badan Pusat Statistik Republik Indonesia (2011), pisang merupakan buah dengan produksi tertinggi dibandingkan buah lain, yaitu sebesar 6.132.695 ton.

Satuhu dan Supriyadi (1994) menyebutkan bahwa pisang memiliki umur 
simpan yang relatif singkat yaitu sekitar 14 hari setelah pemanenan. Hal ini tentu menjadi masalah karena produktivitas pisang di Indonesia sangat tinggi. Tidak semua hasil produksi pisang dapat dikonsumsi dalam bentuk buah segar, sehingga diperlukan cara untuk memperpanjang umur simpan pisang yaitu dengan membuatnya menjadi produk olahan seperti sale, keripik, buah kaleng, manisan kering atau basah. Salah satu jenis produk buah-buahan yang kering selain manisan adalah fruit leather.

Fruit leather merupakan suatu bentuk olahan buah-buahan yang mempunyai nilai ekonomis di pasar internasional. Fruit leather berbentuk lembaran tipis dengan ketebalan 2-3 mm, kadar air 10-15\%, mempunyai konsistensi dan rasa khas sesuai dengan jenis buah-buahan yang digunakan (Asben, 2007). Produk ini umumnya berasal dari buah-buahan tropis yang berkadar air tidak terlalu tinggi namun tinggi kandungan seratnya seperti pisang. Banyak varietas pisang yang masih mempunyai nilai jual relatif rendah sebagai buah meja, di antaranya pisang kapas, pisang kepok, dan pisang nangka. Selain untuk diversifikasi pangan, pengolahan jenis-jenis pisang tersebut menjadi fruit leather diharapkan bisa meningkatkan nilai ekonomisnya.

Nurainy dan Koesoemawardani (2006) menyebutkan bahwa masalah yang sering timbul pada fruit leather adalah plastisitasnya yang kurang baik pada buahbuah tertentu. Oleh sebab itu dalam pembuatan fruit leather dapat ditambahkan bahan hidrokoloid untuk memperbaiki tekstur. Berdasarkan penelitian Gujral dan Brar (2003), penambahan hidrokoloid (guar gum, pektin, carboxymethyl cellulose, gum acacia, dan sodium alginat) dapat memperbaiki tekstur fruit leather mangga. Rumput laut (alga merah dan cokelat) merupakan sumber utama dari hidrokoloid (Glicksman, 1983). Di Indonesia, beberapa penelitian sebelumnya menggunakan rumput laut jenis Kappaphycus alvarezii (Eucheuma cottonii) sebagai bahan tambahan dalam pembuatan fruit leather. Selain dapat menambah plastisitas, rumput laut juga dapat memperkaya kandungan gizi dalam fruit leather di antaranya karbohidrat, serat, dan mineral. Kehadiran fruit leather pisang dengan penambahan rumput laut dapat menjadi alternatif snack yang praktis, sehat, dan bergizi untuk masyarakat.

Penelitian ini bertujuan untuk mengetahui karakteristik kimia (kadar air, kadar abu, kadar gula reduksi, dan kadar serat pangan) dan sensoris fruit leather yang dibuat dari beberapa varietas pisang dengan variasi penambahan rumput laut, serta untuk mendapatkan fruit leather terbaik berdasarkan karakteristik kimia dan karakteristik sensoris pada masing-masing varietas pisang yang digunakan.

\section{METODE PENELITIAN}

\section{Bahan dan Alat}

Bahan yang digunakan untuk membuat fruit leather adalah pisang kapas, pisang kepok kuning, dan pisang nangka yang didapat dari Pasar Legi Surakarta dan dipilih yang telah masak sempurna. Rumput laut jenis Kappaphycus alvarezii dalam bentuk kering yang diperoleh dari Pasar Legi Surakarta. Sedangkan bahan-bahan lainnya adalah gula pasir (Gulaku) yang diperoleh di toko swalayan di Surakarta dan jeruk nipis yang diperoleh dari Pasar Legi Surakarta. Bahan kimia yang digunakan untuk analisis antara lain glukosa $\left(\mathrm{C}_{6} \mathrm{H}_{12} \mathrm{O}_{6}\right)$, reagensia Nelson, reagensia Arsenomolybdat, buffer fosfat, enzim thermamyl, enzim pankreatin, asam klorida $(\mathrm{HCl} 4 \mathrm{~N})$, natrium hidroksida $(\mathrm{NaOH} 4 \mathrm{~N})$, etanol $\left(\mathrm{C}_{2} \mathrm{H}_{5} \mathrm{OH}\right) 95 \%$, aseton $\left(\mathrm{CH}_{3} \mathrm{COCH}_{3}\right)$, dan aquades.

Alat yang digunakan untuk pembuatan fruit leather yaitu oven (Kirin KBO-90RA), blender (Kirin KBB-210G), loyang alumunium $(25 \times 25 \mathrm{~cm})$, panci, kompor, gelas ukur, dan pisau. Sedangkan alat untuk analisis yaitu oven (Memmert), timbangan analitik (Ohaus Adventurer ${ }^{\mathrm{TM}}$ ), spektrofotometer (UV mini 1240 Shimadzu), alat sokhlet botol timbang (Pyrex Iwaki), tanur abu, krus porselen, desikator, kompor listrik, vortex, tabung reaksi (Pyrex Iwaki), pipet volume, erlenmeyer (Pyrex Iwaki), labu takar (Pyrex Iwaki), mortar, pH meter, kertas saring, cawan, nampan, dan borang. 


\section{Tahapan Penelitian}

\section{Persiapan Sampel}

Pisang kapas, pisang kepok kuning, dan pisang nangka dipilih dengan tingkat kematangan penuh yang seragam. Rumput laut yang digunakan yaitu jenis Kappaphycus alvarezii. Sebelum digunakan, rumput laut dibersihkan dan direndam dalam air selama kurang lebih 24 jam.

\section{Pembuatan Fruit Leather}

\section{Pembuatan bubur}

Pembuatan bubur pisang dan bubur rumput laut menggunakan metode Ekanayake dan Bandara (2002) dengan modifikasi. Pisang matang di-steam 3 menit, dikupas, dipotong-potong, dan dimasukkan dalam blender. Selanjutnya ditambahkan $15 \%$ gula pasir dan $1 \%$ air jeruk nipis ke dalam blender. Penambahan gula pasir $15 \%$ merupakan hasil terbaik dalam penelitian fruit leather pisang Ekanayake dan Bandara (2002). Penambahan 1\% air jeruk nipis sebagai pengganti $1 \%$ potassium metabisulfit dan $0,75 \%$ asam sitrat yang digunakan Ekanayake dan Bandara (2002). Modifikasi lain yaitu penambahan rumput laut (Kappaphycus alvarezii). Rumput laut disteam 3 menit, selanjutnya dimasukkan ke dalam blender berisi pisang dan air jeruk nipis sesuai formulasi untuk diblender selama 5 menit hingga menjadi bubur. Formulasi yang digunakan dapat dilihat pada Tabel 1.

Tabel 1. Formulasi Pisang dan Rumput Laut dalam Pembuatan Fruit Leather

\begin{tabular}{ll}
\hline Kode & \multicolumn{1}{c}{ Keterangan } \\
\hline $\mathrm{KaR}_{1}$ & Pisang kapas 100\% \\
$\mathrm{KaR}_{2}$ & Pisang kapas 92,5\% + rumput laut 7,5\% \\
$\mathrm{KaR}_{3}$ & Pisang kapas 85\% + rumput laut 15\% \\
$\mathrm{KeR}_{1}$ & Pisang kepok kuning 100\% \\
$\mathrm{KeR}_{2}$ & Pisang kepok kuning 92,5\% + rumput \\
& laut 7,5\% \\
$\mathrm{KeR}_{3}$ & Pisang kepok kuning 85\% + rumput laut \\
& $15 \%$ \\
$\mathrm{NaR}_{1}$ & Pisang nangka 100\% \\
$\mathrm{NaR}_{2}$ & Pisang nangka 92,5\% + rumput laut \\
& $7,5 \%$ \\
$\mathrm{NaR}_{3}$ & Pisang nangka 85\% + rumput laut 15\% \\
\end{tabular}

\section{Pencetakan}

Bubur dihamparkan dalam loyang yang telah dilapisi plastik. Ketebalan bubur 3 mm sesuai metode Mukisa et al. (2010).

\section{Pengeringan}

Bubur yang telah dicetak tersebut selanjutnya dikeringkan menggunakan oven dengan suhu $50^{\circ} \mathrm{C}$ selama 6 jam. Setiap 30 menit dilakukan pertukaran posisi loyang supaya aliran panas merata. Fruit leather yang dihasilkan selanjutnya dipotong-potong dengan ukuran $10 \times 4 \mathrm{~cm}$ dan dikemas dalam plastic polietilen untuk dianalisis.

\section{Analisis}

Fruit leather yang dihasilkan selanjutnya dianalisis karakteristik kimianya meliputi kadar air menggunakan metode thermogravimetri (AOAC, 1970), kadar abu menggunakan metode langsung (Sudarmadji dkk, 1997), kadar gula reduksi menggunakan metode Nelson-Somogyi (Sudarmadji dkk, 1997), dan kadar serat pangan menggunakan metode Multi Enzim (Asp dan Johansson, 1981) serta karakteristik sensoris menggunakan uji kesukaan (hedonik) (Kartika dkk, 1988).

\section{HASIL DAN PEMBAHASAN}

\section{Karakteristik Kimia Fruit Leather Beberapa Varietas Pisang}

\section{Kadar Air}

Berdasarkan Tabel 2 dapat dilihat bahwa kadar air fruit leather pisang kapas formula $\mathrm{R}_{1}$ sebesar 16,28\%; $\mathrm{R}_{2}$ sebesar $16,17 \%$; dan $\mathrm{R}_{3}$ sebesar $14,85 \%$. Kadar air fruit leather pisang kepok kuning formula $\mathrm{R}_{1}$ sebesar 13,46\%; $\mathrm{R}_{2}$ sebesar 11,93\%; dan $\mathrm{R}_{3}$ sebesar 10,51\%. Kadar air fruit leather pisang nangka formula $\mathrm{R}_{1}$ sebesar $13,87 \%$; $\mathrm{R}_{2}$ sebesar $13,72 \%$; dan $\mathrm{R}_{3}$ sebesar $13,69 \%$. Semakin tinggi konsentrasi rumput laut yang ditambahkan, kadar air fruit leather semua varietas pisang semakin menurun. Penurunan kadar air disebabkan kadar air rumput laut lebih kecil dibandingkan kadar air pada semua jenis pisang yang digunakan. Kadar air rumput laut sebesar 27,8\% (Sulistyowaty, 
Tabel 2. Karakteristik Kimia Fruit Leather Beberapa Varietas Pisang

\begin{tabular}{|c|c|c|c|c|c|c|c|c|c|}
\hline \multirow[t]{3}{*}{ Parameter } & \multicolumn{9}{|c|}{ Fruit Leather Beberapa Varietas Pisang } \\
\hline & \multicolumn{3}{|c|}{$\begin{array}{c}\text { Fruit Leather Pisang } \\
\text { Kapas }\end{array}$} & \multicolumn{3}{|c|}{$\begin{array}{l}\text { Fruit Leather Pisang } \\
\text { Kepok Kuning }\end{array}$} & \multicolumn{3}{|c|}{$\begin{array}{c}\text { Fruit Leather Pisang } \\
\text { Nangka }\end{array}$} \\
\hline & $\mathbf{R}_{1}$ & $\mathbf{R}_{2}$ & $\mathbf{R}_{3}$ & $\mathbf{R}_{1}$ & $\mathbf{R}_{2}$ & $\mathbf{R}_{\mathbf{3}}$ & $\mathbf{R}_{1}$ & $\mathbf{R}_{2}$ & $\mathbf{R}_{\mathbf{3}}$ \\
\hline Kadar Air $\left.^{*}\right)$ & $16,28^{b}$ & $16,17^{\mathrm{b}}$ & $14,85^{\mathrm{a}}$ & $13,46^{\mathrm{c}}$ & $11,93^{\mathrm{b}}$ & $10,51^{\mathrm{a}}$ & $13,87^{\mathrm{a}}$ & $13,72^{\mathrm{a}}$ & $13,69^{\mathrm{a}}$ \\
\hline Kadar Abu $\left.{ }^{*}\right)$ & $1,74^{\mathrm{a}}$ & $1,83^{\mathrm{b}}$ & $2,03^{\mathrm{c}}$ & $1,64^{\mathrm{a}}$ & $1,72^{\mathrm{a}}$ & $2,02^{\mathrm{b}}$ & $1,88^{\mathrm{a}}$ & $1,98^{\mathrm{a}}$ & $2,3^{\mathrm{b}}$ \\
\hline $\begin{array}{l}\text { Kadar Gula } \\
\left.\text { Reduksi }^{*}\right)\end{array}$ & $43,47^{\mathrm{a}}$ & $62,50^{\mathrm{b}}$ & $64,47^{\mathrm{b}}$ & $31,20^{\mathrm{a}}$ & $38,17^{\mathrm{a}}$ & $39,06^{\mathrm{a}}$ & $26,82^{\mathrm{a}}$ & $52,48^{\mathrm{b}}$ & $54,60^{\mathrm{b}}$ \\
\hline $\begin{array}{l}\text { Kadar Serat } \\
\left.\text { Pangan }{ }^{*}\right)\end{array}$ & $6,25^{\mathrm{a}}$ & $6,75^{\mathrm{b}}$ & $6,93^{\mathrm{b}}$ & $8,31^{\mathrm{a}}$ & $9,18^{\mathrm{ab}}$ & $9,36^{\mathrm{b}}$ & $5,54^{\mathrm{a}}$ & $5,99^{\mathrm{b}}$ & $6,52^{c}$ \\
\hline Keterangan: & $\begin{array}{l}\mathrm{R}_{1}=\mathrm{Pis} \\
\text { ditanda } \\
\text { sama, } \\
\left.{ }^{*}\right) \mathrm{dal}\end{array}$ & wb & Pisal & $\%+1$ & $\begin{array}{l}\text { taut } \\
\text { s yan } \\
\text { n }(\alpha=\end{array}$ & $\begin{array}{l}\mathrm{R}_{3}= \\
\text { dal }\end{array}$ & $85^{\circ}$ & & \\
\hline
\end{tabular}

2009). Sedangkan kadar air pisang menurut DeMan (1997) sebesar 75\%.

\section{Kadar Abu}

Berdasarkan Tabel 2 dapat dilihat bahwa kadar abu fruit leather pisang kapas formula $\mathrm{R}_{1}$ sebesar $1,74 \%$; $\mathrm{R}_{2}$ sebesar $1,83 \%$; dan $\mathrm{R}_{3}$ sebesar 2,03\%. Kadar abu fruit leather pisang kepok kuning formula $\mathrm{R}_{1}$ sebesar 1,64\%; $\mathrm{R}_{2}$ sebesar 1,72\%; dan $\mathrm{R}_{3}$ sebesar 2,02\%. Kadar abu fruit leather pisang nangka formula $\mathrm{R}_{1}$ sebesar $1,88 \% ; \mathrm{R}_{2}$ sebesar 1,98\%; dan $R_{3}$ sebesar $2,3 \%$. Semakin tinggi konsentrasi rumput laut yang ditambahkan, kadar abu fruit leather semua varietas pisang semakin meningkat. Hal ini disebabkan oleh kadar abu dalam rumput laut lebih tinggi dari pisang. Rumput laut jenis Kappaphycus alvarezii mengandung abu sebesar 10,47\% (basis kering) (Santoso et al., 2004). Sedangkan pisang mengandung mineral sebesar 0,04\% (Cahyono, 1995).

\section{Kadar Gula Reduksi}

Berdasarkan Tabel 2 dapat dilihat bahwa kadar gula reduksi fruit leather pisang kapas formula $\mathrm{R}_{1}$ sebesar $43,47 \%$; $\mathrm{R}_{2}$ sebesar $62,50 \%$; dan $\mathrm{R}_{3}$ sebesar $64,47 \%$. Kadar gula reduksi fruit leather pisang kepok kuning formula $\mathrm{R}_{1}$ sebesar $31,20 \% ; \mathrm{R}_{2}$ sebesar $38,17 \%$; dan $\mathrm{R}_{3}$ sebesar $39,06 \%$. Kadar gula reduksi fruit leather pisang nangka formula $\mathrm{R}_{1}$ sebesar $26,82 \% ; \mathrm{R}_{2}$ sebesar $52,48 \%$; dan $\mathrm{R}_{3}$ sebesar 54,60\%. Semakin tinggi konsentrasi rumput laut yang ditambahkan, kadar gula reduksi fruit leather semua varietas pisang semakin meningkat. Hal ini disebabkan oleh sukrosa yang ditambahkan dalam proses pembuatan fruit leather mengalami hidrolisis karena bereaksi dengan asam dari air jeruk nipis dan gugus ester asam kuat pada rumput laut. Karaginan merupakan hasil ekstraksi rumput laut yang mengandung gugus ester asam sulfat (DeMan, 1997).

\section{Kadar Serat Pangan}

Berdasarkan Tabel 2 dapat diketahui bahwa kadar serat pangan fruit leather pisang kapas formula $\mathrm{R}_{1}$ sebesar $6,25 \%$; $\mathrm{R}_{2}$ sebesar $6,75 \%$; dan $\mathrm{R}_{3}$ sebesar $6,93 \%$. Kadar serat pangan fruit leather pisang kepok kuning formula $\mathrm{R}_{1}$ sebesar $8,31 \%$; $\mathrm{R}_{2}$ sebesar $9,18 \%$; dan $\mathrm{R}_{3}$ sebesar $9,36 \%$. Kadar serat pangan fruit leather pisang nangka formula $\mathrm{R}_{1}$ sebesar 5,54\%; $\mathrm{R}_{2}$ sebesar 5,99\%; dan $\mathrm{R}_{3}$ sebesar $6,52 \%$. Kadar serat pangan cenderung meningkat seiring meningkatnya konsentrasi rumput laut yang ditambahkan pada fruit leather semua varietas pisang. Hal ini diduga disebabkan kadar serat pangan dalam rumput laut lebih tinggi dari serat pangan dalam pisang. Dalam $100 \mathrm{~g}$ pisang terkandung serat sebanyak 0,7 g (Cahyono, 1995). Dalam 100 g rumput laut terkandung serat pangan total sebesar 69,3 g (basis kering) (Santoso et al., 2004).

\section{Karakteristik Sensori Fruit Leather Beberapa Varietas Pisang}

\section{Warna}

Berdasarkan Tabel 3 dapat dilihat bahwa nilai rata-rata kesukaan panelis terhadap warna fruit leather pisang kapas berkisar antara 2,20-2,64; fruit leather pisang kepok kuning 3,04-3,60; dan fruit leather pisang nangka 3,96-4,08. Rata-rata fruit 
Tabel 3. Karakteristik Sensoris Fruit Leather Beberapa Varietas Pisang

\begin{tabular}{|c|c|c|c|c|c|c|c|c|c|}
\hline \multirow[t]{3}{*}{ Parameter } & \multicolumn{9}{|c|}{ Fruit Leather Beberapa Varietas Pisang } \\
\hline & \multicolumn{3}{|c|}{$\begin{array}{c}\text { Fruit Leather Pisang } \\
\text { Kapas }\end{array}$} & \multicolumn{3}{|c|}{$\begin{array}{c}\text { Fruit Leather Pisang } \\
\text { Kepok Kuning }\end{array}$} & \multicolumn{3}{|c|}{$\begin{array}{c}\text { Fruit Leather Pisang } \\
\text { Nangka }\end{array}$} \\
\hline & $\mathbf{R}_{1}$ & $\mathbf{R}_{2}$ & $\mathbf{R}_{\mathbf{3}}$ & $\mathbf{R}_{1}$ & $\mathbf{R}_{2}$ & $\mathbf{R}_{\mathbf{3}}$ & $\mathbf{R}_{1}$ & $\mathbf{R}_{2}$ & $\mathbf{R}_{\mathbf{3}}$ \\
\hline Warna & $2,64^{\mathrm{a}}$ & $2,52^{\mathrm{a}}$ & $2,20^{\mathrm{a}}$ & $3,60^{\mathrm{b}}$ & $3,04^{\mathrm{a}}$ & $3,32^{\mathrm{ab}}$ & $4,00^{\mathrm{a}}$ & $4,08^{\mathrm{a}}$ & $3,96^{\mathrm{a}}$ \\
\hline Aroma & $3,40^{\mathrm{a}}$ & $3,20^{\mathrm{a}}$ & $3,08^{\mathrm{a}}$ & $3,28^{\mathrm{a}}$ & $3,08^{\mathrm{a}}$ & $3,40^{\mathrm{a}}$ & $3,28^{\mathrm{a}}$ & $3,40^{\mathrm{a}}$ & $3,28^{\mathrm{a}}$ \\
\hline Rasa & $3,76^{\mathrm{b}}$ & $3,84^{\mathrm{b}}$ & $3,20^{\mathrm{a}}$ & $3,36^{\mathrm{a}}$ & $3,24^{\mathrm{a}}$ & $3,16^{\mathrm{a}}$ & $3,20^{\mathrm{a}}$ & $3,52^{\mathrm{a}}$ & $3,48^{\mathrm{a}}$ \\
\hline Tekstur & $3,44^{\mathrm{b}}$ & $3,20^{\mathrm{b}}$ & $2,64^{\mathrm{a}}$ & $3,04^{b}$ & $2,68^{\mathrm{ab}}$ & $2,28^{\mathrm{a}}$ & $3,32^{\mathrm{a}}$ & $3,48^{\mathrm{a}}$ & $2,96^{\mathrm{a}}$ \\
\hline Overall & $3,32^{\mathrm{ab}}$ & $3,40^{\mathrm{b}}$ & $2,92^{\mathrm{a}}$ & $3,28^{\mathrm{a}}$ & $3,04^{\mathrm{a}}$ & $2,96^{\mathrm{a}}$ & $3,60^{\mathrm{a}}$ & $3,60^{\mathrm{a}}$ & $3,48^{\mathrm{a}}$ \\
\hline Keterangan: & $\begin{array}{l}\mathrm{R}_{1}=\mathrm{Pis} \\
\text { ditanda } \\
\text { sama, } \\
\end{array}$ & $\begin{array}{l}100 \% \\
\text { engan } \\
\text { arti terc }\end{array}$ & $\begin{array}{l}\mathrm{R}_{2}=\mathrm{Pisa} \\
\text { uruf yan } \\
\text { pat beda }\end{array}$ & $92,5 \%$ & $\begin{array}{l}\text { rumpu } \\
\text { ada bari } \\
\text { erlakua }\end{array}$ & $\begin{array}{l}\text { ut } 7,5 \\
\text { ang sa } \\
\alpha=0,05\end{array}$ & $\mathrm{R}_{3}=\mathrm{Pi}$ & ng $85 \%$ & rumpr \\
\hline
\end{tabular}

leather yang dihasilkan memiliki warna kuning hingga kuning kecoklatan dan mengkilat. Warna kuning disebabkan karotenoid pada pisang (DeMan, 1997). Warna kecoklatan disebabkan terjadi reaksi Maillard (Winarno, 1996). Warna mengkilat disebabkan adanya penambahan sukrosa karena gula mempunyai kemampuan membentuk kristal (DeMan, 1997).

\section{Aroma}

Berdasarkan Tabel 3 dapat dilihat bahwa nilai rata-rata kesukaan panelis terhadap aroma fruit leather pisang kapas berkisar antara 3,08-3,40; fruit leather pisang kepok kuning 3,08-3,40; dan fruit leather pisang nangka 3,28-3,40. Fruit leather semua varietas pisang yang dihasilkan memiliki aroma khas pisang dan sedikit asam. Aroma khas pisang ditimbulkan dari ester amil (DeMan, 1997). Aroma asam disebabkan air jeruk nipis.

\section{Rasa}

Berdasarkan Tabel 3 dapat dilihat bahwa nilai rata-rata kesukaan panelis terhadap rasa fruit leather pisang kapas berkisar antara 3,20-3,84; fruit leather pisang kepok kuning antara 3,16-3,36; dan fruit leather pisang nangka antara 3,20-3,52. Fruit leather semua varietas pisang yang yang dugunakan rata-rata menghasilkan rasa khas pisang, manis, dan agak asam. Rasa manis disebabkan adanya monosakarida (Lehninger, 1982). Rasa asam disebabkan asam sitrat dari air jeruk nipis (Sarwono, 2006). Pada fruit leather pisang nangka, rasa asam juga dipengaruhi oleh rasa masam dari buah pisang nangka sendiri (Cahyono, 1995).

\section{Tekstur}

Berdasarkan Tabel 3 dapat dilihat bahwa nilai rata-rata kesukaan panelis terhadap tekstur fruit leather pisang kapas berkisar antara 2,64-3,44; fruit leather pisang kepok kuning 2,28-3,04; dan fruit leather pisang nangka 2,96-3,48. Fruit leather yang dihasilkan memiliki tekstur yang mudah sobek ketika digigit dan dikunyah hingga tekstur yang keras. Pada fruit leather pisang kapas dan fruit leather pisang kepok kuning terdapat kecenderungan terjadi penurunan tingkat kesukaan terhadap tekstur dengan semakin tingginya konsentrasi rumput laut yang ditambahkan. Hal ini disebabkan semakin tinggi jumlah kappa karaginan, semakin keras tekstur yang dihasilkan karena karakteristik gel kappa karaginan kuat dan rapuh dengan sineresis (Glicksman, 1983).

\section{Overall}

Berdasarkan Tabel 3 dapat dilihat bahwa nilai rata-rata kesukaan panelis terhadap parameter overall fruit leather pisang kapas berkisar antara 2,92-3,40; fruit leather pisang kepok kuning 2,96-3,28; dan fruit leather pisang nangka 3,48-3,60. Overall fruit leather yang dihasilkan diterima hingga disukai.

\section{Penentuan Karakteristik Fruit Leather Beberapa Varietas Pisang yang Terpilih}

Berdasarkan Tabel 4 dapat dilihat bahwa fruit leather formula $\mathrm{R}_{3}$ pada semua varietas pisang memiliki kadar abu, kadar gula reduksi, dan kadar serat pangan tertinggi dibandingkan formula lainnya pada varietas pisang yang sama. Selain itu, fruit leather formula $\mathrm{R}_{3}$ menghasilkan kadar air terendah. 
Tabel 4. Matriks Pemilihan Fruit Leather Beberapa Varietas Pisang Berdasarkan Karakteristik Kimia dan Sensoris

\begin{tabular}{|c|c|c|c|c|c|c|c|c|c|}
\hline \multirow[t]{3}{*}{ Parameter } & \multicolumn{9}{|c|}{ Fruit Leather Beberapa Varietas Pisang } \\
\hline & \multicolumn{3}{|c|}{$\begin{array}{c}\text { Fruit Leather Pisang } \\
\text { Kapas }\end{array}$} & \multicolumn{3}{|c|}{$\begin{array}{c}\text { Fruit Leather Pisang Kepok } \\
\text { Kuning }\end{array}$} & \multicolumn{3}{|c|}{$\begin{array}{c}\text { Fruit Leather Pisang } \\
\text { Nangka }\end{array}$} \\
\hline & $\mathbf{R}_{1}$ & $\mathbf{R}_{2}$ & $\mathbf{R}_{3}$ & $\mathbf{R}_{1}$ & $\mathbf{R}_{2}$ & $\mathbf{R}_{3}$ & $\mathbf{R}_{1}$ & $\mathbf{R}_{2}$ & $\mathbf{R}_{3}$ \\
\hline Kadar Air $\left.{ }^{*}\right)$ & $16,28^{b}$ & $16,17^{\mathrm{b}}$ & $\overline{\left.14,85^{a}\right)}$ & $13,46^{\mathrm{c}}$ & $11,93^{b}$ & $10,51^{a}$ & $13,87^{\mathrm{a}}$ & $13,72^{\mathrm{a}}$ & $\overline{13}, \mathbf{6 9}^{\mathrm{a}}$ \\
\hline Kadar Abu *) & $1,74^{\mathrm{a}}$ & $1,83^{\mathrm{b}}$ & $2,03^{c}$ & $1,64^{\mathrm{a}}$ & $1,72^{\mathrm{a}}$ & $2,02^{b}$ & $1,88^{\mathrm{a}}$ & $1,98^{\mathrm{a}}$ & $2,3^{b}$ \\
\hline $\begin{array}{l}\text { Kadar Gula } \\
\text { Reduksi }^{*}\end{array}$ & $43,47^{\mathrm{a}}$ & $62,50^{\mathrm{b}}$ & $64,47^{b}$ & $31,20^{\mathrm{a}}$ & $38,17^{\mathrm{a}}$ & $39,06^{\mathrm{a}}$ & $26,82^{\mathrm{a}}$ & $52,48^{\mathrm{b}}$ & $54,60^{b}$ \\
\hline $\begin{array}{l}\text { Kadar Serat } \\
\text { Pangan *) }\end{array}$ & $6,25^{\mathrm{a}}$ & $6,75^{\mathrm{b}}$ & $6,93^{b}$ & $8,31^{\mathrm{a}}$ & $9,18^{\mathrm{ab}}$ & $9,36^{b}$ & $5,54^{\mathrm{a}}$ & $5,99^{\mathrm{b}}$ & $6,52^{\mathrm{c}}$ \\
\hline Warna & $2,64^{\mathrm{a}}$ & $2,52^{\mathrm{a}}$ & $2,20^{\mathrm{a}}$ & $3,60^{b}$ & $3,04^{\mathrm{a}}$ & $3,32^{\mathrm{ab}}$ & $4,00^{\mathrm{a}}$ & $4,08^{a}$ & $3,96^{\mathrm{a}}$ \\
\hline Aroma & $3,40^{\mathrm{a}}$ & $3,20^{\mathrm{a}}$ & $3,08^{\mathrm{a}}$ & $3,28^{\mathrm{a}}$ & $3,08^{\mathrm{a}}$ & I $3,40^{\mathrm{a}}$ & $3,28^{\mathrm{a}}$ & $3,40^{a}$ & $3,28^{\mathrm{a}}$ \\
\hline Rasa & $3,76^{\mathrm{b}}$ & $3,84^{b}$ & $3,20^{\mathrm{a}}$ & $3,36^{a}$ & $3,24^{\mathrm{a}}$ & I $3,16^{\mathrm{a}}$ & $3,20^{\mathrm{a}}$ & $3,52^{a}$ & $3,48^{\mathrm{a}}$ \\
\hline Tekstur & $3,44^{b}$ & $3,20^{\mathrm{b}}$ & $2,64^{\mathrm{a}}$ & $3,04^{b}$ & $2,68^{\mathrm{ab}}$ & $2,28^{\mathrm{a}}$ & $3,32^{\mathrm{a}}$ & $3,48^{a}$ & $2,96^{\mathrm{a}}$ \\
\hline Overall & $3,32^{\mathrm{ab}}$ & $3,40^{b}$ & $2,92^{\mathrm{a}}$ & $3,28^{\mathrm{a}}$ & $3,04^{\mathrm{a}}$ & i $2,96^{\mathrm{a}}$ & $3,60^{\mathrm{a}}$ & $3,60^{a}$ & $3,48^{\mathrm{a}}$ \\
\hline & $\begin{array}{l}=\text { Pisang } \\
\text { andai d } \\
\text { na, bera } \\
\text { dalam \% } \\
\text { or warn } \\
\text { sangat s } \\
\text { ita yang }\end{array}$ & $\begin{array}{l}0 \% ; \mathrm{R}_{2} \\
\text { an huru } \\
\text { erdapat } \\
\text { aroma, } \\
\text { etak teb }\end{array}$ & $\begin{array}{l}\text { isang } 92 \\
\text { ang berb } \\
\text { da nyata } \\
\text { sa, tekst } \\
\text { merupak } \\
\text { Fruit lec }\end{array}$ & $\begin{array}{l}\text { + run } \\
\text { pada } \\
\text { perlal } \\
\text { dan } o \\
\text { asil tel } \\
\text { pisan }\end{array}$ & $\begin{array}{l}\text { laut } 7 \text {, } \\
\text { yang } \\
(\alpha=0,0 \\
l l: 1=\mathrm{s} \\
\text { per pa } \\
\text { pas terp }\end{array}$ & $\begin{array}{l}; \mathrm{R}_{3}=\text { Pisan } \\
\text { ha dalam } \mathrm{k} \\
\text { gat tidak } \mathrm{s} \\
\text { neter pada } \\
\mathrm{g} \text { terpilih }\end{array}$ & $\begin{array}{l}\text { g } 85 \%+1 \\
\text { olom fruit } \\
\text { uka, 2=tic } \\
\text { fruit leathe }\end{array}$ & $\begin{array}{l}\text { uka, } 3 \\
\text {-tiap }\end{array}$ & $\begin{array}{l}\text { Data yang } \\
\text { pisang yang } \\
\text { ral, } 4=\text { suka, } \\
\text { as pisang. }\end{array}$ \\
\hline
\end{tabular}

Berdasarkan hasil analisis sensoris, penambahan rumput laut rata-rata tidak berpengaruh signifikan terhadap tingkat penerimaan panelis. Fruit leather semua varietas pisang rata-rata diterima panelis, sehingga fruit leather terpilih adalah formula $\mathrm{R}_{3}$ pada masing-masing varietas pisang yang digunakan.

\section{KESIMPULAN DAN SARAN}

\section{Kesimpulan}

1. Kadar air fruit leather pisang kapas 14,85$16,28 \%$; fruit leather pisang kepok kuning 10,51-13,46\%; dan fruit leather pisang nangka 13,69-13,87\%. Kadar abu fruit leather pisang kapas 1,74-2,03\%; fruit leather pisang kepok kuning 1,64-2,02\%; dan fruit leather pisang nangka 1,88-2,3\%. Kadar gula reduksi fruit leather pisang kapas 43,47-64,47\%; fruit leather pisang kepok kuning 31,20-39,06\%; dan fruit leather pisang nangka 26,82-54,60\%. Kadar serat pangan fruit leather pisang kapas 6,25-6,93\%; fruit leather pisang kepok kuning 8,31-9,36\%; dan fruit leather pisang nangka 5,54-6,52\%.
2. Warna fruit leather semua varietas pisang rata-rata diterima hingga disukai, aroma diterima panelis, rasa diterima hingga disukai panelis, tekstur rata-rata diterima panelis, dan overall diterima hingga disukai oleh panelis.

3. Penentuan Karakteristik Fruit Leather Beberapa Varietas Pisang yang Terpilih

Fruit leather terpilih yaitu fruit leather dengan penambahan $15 \%$ rumput laut pada semua varietas pisang yang digunakan.

\section{Saran}

Fruit leather dengan penambahan $15 \%$ rumput laut pada semua varietas pisang yang digunakan berpotensi untuk dikembangkan menjadi produk komersial.

\section{DAFTAR PUSTAKA}

AOAC. 1970. Official Methods of Analysis of the Association of Official Analytical Chemists. Washington, DC.

Asben, A. 2007. Peningkatan Kadar Iodium dan Serat Pangan dalam Pembuatan Fruit Leathers Nenas (Ananas comosus Merr) dengan Penambahan Rumput Laut. 
Penelitian. Fakultas Pertanian Universitas Andalas. Padang.

Asp, N. G. dan C. G. Johansson. 1981. In W. P. T. James, and O. Theander (Eds.), The Analysis of Dietary Fiber in Food (pp. 173-189). Marcel Dekker. New York.

Badan Pusat Statistik Republik Indonesia. 2011. Produksi Buah-buahan Menurut Provinsi (Ton), 2011. http://www.bps.go.id/tab_sub/view.php?t abel=1\&daftar=1\&id_subyek=55\&notab $=2$. Diakses pada hari Kamis tanggal 16 Mei 2013.

Cahyono, B. 1995. Pisang, Budidaya, dan Analisis Usahatani. Penerbit Kanisius. Yogyakarta.

DeMan, J. M. 1997. Kimia Makanan. Penerbit ITB. Bandung.

Ekanayake, S. dan L. Bandara. 2002. Development of Banana Fruit Leather. Annals of the Sri Lanka Department of Agriculture. 4: 353-358.

Glicksman, M. 1983. Food Hydrocolloids, vol 2, Seaweed Extracts. CRC Press. Boca Raton, FL. Pp. 63-73.

Gujral, H. S. dan S. S. Brar. 2003. Effect of Hydrocolloids on the Dehydration Kinetics, Color, and Texture Mango Leather. International Journal of Food Properties. Vol. 6, Issue 2: 269-279.

Kartika B. P., Hastuti, dan W. Supartono. 1988. Pedoman Uji Inderawi Bahan Pangan. UGM Press. Yogyakarta.

Lehninger, A. L. 1982. Dasar-Dasar Biokimia Jilid I. Penerbit Erlangga. Jakarta.

Mukisa, I. M., S. Okilya, dan A. N. Kaaya. 2010. Effect of Solar Drying on the Quality and Acceptability of Jackfruit Leather. Electronic Journal of
Enviromental, Agricultural and Food Chemistry. 9 (1): 101-111.

Nurainy, F. dan D. Koesoemawardani. 2006. Efek Penambahan Rumput Laut terhadap Karakteristik Fruit Leather Sirsak. Penelitian. Fakultas Pertanian Universitas Lampung. Bandar Lampung.

Santoso, J., Yumiko, Y., dan Takeshi, S. 2004. Mineral, Fatty Acid, and Dietary Fiber Compositions in Several Indonesian Seaweeds. Jurnal Ilmu Perairan dan Perikanan Indonesia. Vol. II, No. 1: 45-51.

Sarwono, B. 2006. Khasiat dan Manfaat Jeruk Nipis. AgroMedia Pustaka. Jakarta.

Satuhu, S. dan A. Supriyadi. 1994. Pisang, Budidaya, Pengolahan, dan Prospek Pasar. PT. Penebar Swadaya. Jakarta.

Sudarmadji, S., B. Haryono, dan Suhardi. 1997. Prosedur Analisa Bahan untuk Bahan Makanan dan Pertanian. Penerbit Liberty. Yogyakarta.

Sulistyowaty, D. 2009. Efek Diet Rumput Laut Eucheuma sp. terhadap Kadar Glukosa Darah Tikus Wistar yang Disuntik Aloksan. Laporan Akhir Penelitian Karya Tulis Ilmiah. Fakultas Kedokteran Universitas Diponegoro. Semarang.

Winarno, F. G. 1996. Kimia Pangan dan Gizi. PT. Gramedia Pustaka Utama. Jakarta. 